\title{
Studies on Sensory Properties of Dahi Blended with Biofortified Bajra Flour
}

\author{
R. V. More ${ }^{1^{*}}$, B. M. Thombre ${ }^{2}$, S. G. Narwade ${ }^{3}$ and V. Y. Sawant ${ }^{2}$ \\ ${ }^{1}$ Department of Animal Husbandry and Dairy Science, \\ ${ }^{2}$ College of Agriculture, VNMKV, Parbhani, India \\ ${ }^{3} \mathrm{COA}$, Ambajogai, India \\ *Corresponding author
}

\section{A B S T R A C T}

\begin{tabular}{l} 
Ke y w or d s \\
Dahi, Flour, \\
Sensory, \\
Buffalo milk \\
\hline Article Info \\
\hline $\begin{array}{l}\text { Accepted: } \\
10 \text { October } 2020 \\
\text { Available Online: } \\
10 \text { November } 2020\end{array}$ \\
\hline
\end{tabular}

\section{Introduction}

Cereals and millets are superior in nutritional quality compared to other fermentable substrates, because these plentiful resources contain some of the necessary minerals, vitamins, sterols, growth factors and dietary fibre, thereby fulfilling the essential nutrient needs of mankind (Chavan and Kadam, 1989). Millets are rich in antioxidants much higher than other major cereal crops so they are used as nutraceuticals (Balasubramanian, 2013). Millets are major food component in various traditional foods and drinks such as bread and porridges, and is also a major source of proteins and carbohydrate, as well as other essential phytonutrients (Habiyaremye et al., 2017).

Fermented foods are of great significance since they provide and preserve vast quantities of nutritious foods in a wide diversity of flavor, aroma, and texture which enrich the human diet. The microorganisms involved in Dahi fermentation include Streptococcus thermophilus, S. lactis, $S$. cremoris, Lactobacillus bulgaricus, $L$. acidophiuls, L. plantarum and lactose fermenting yeasts. When culture is undefined and kept in unhygienic condition it contains 
mixture of various desirable and undesirable strains of bacteria.

The fermented milk-cereal based products are extremely popular in Indian subcontinent and most of the African countries. Cereal-based dairy products are popular or famous across the country and occupy a valued place in the Indian diet, not only for their taste and eating pleasure also due to their high nutritional quality. Some of the fermented foods prepared by incorporating milk-solids are Kindimu (Central African region), Ben-Saalga and Ogi (Nigeria), Rabadi, Dahi-vada, Curd rice (India), Trahanas (Greece), Kishk (Egypt) (Singh, 2007). Pearl millet is rich in resistant starch, insoluble and soluble dietetic fibers, antioxidants and minerals. It contains about 13.6 per cent crude protein, 63.2 per cent starch, 2.1 per cent ash, 2.8 per cent crude fiber, 7.8 per cent crude fat and 92.5 per cent dry matter (Ali and Abdalla, 2003). Pearl millet grains contain $0.38 \mathrm{mg}$ of thiamine, 0.21 $\mathrm{mg}$ riboflavin, and $2.8 \mathrm{mg}$ of niacin (Hulse et al., 1980). Bajra grains contain minerals like iron, phosphorus, magnesium, and calcium in containing appreciable amounts (Burton et al., 1992).

Iron in animal and human nutrition is an important trace element. Iron is active in the cytochrome structures and with other enzymes. It is also a heme component in haemoglobin and myoglobin, in which it plays a significant role in the transport, storage and usage of oxygen (McLean et al., 2007). Micronutrient malnutrition, particularly vitamin A, iron and zinc-related malnutrition, has recently reported to be a most prevalent food-related health problem globally Mason and Garcia 1993). The fortification of milk and dairy products with iron and zinc is considered a possible solution to avoid iron and zinc deficiency disease. Hybrid variety AHB 1200 variety of bajra contains $88 \mathrm{ppm}$ iron while others contain average $40 \mathrm{ppm}$ of iron it also contains 43 ppm zinc. As milk is deficient in Iron, it was decided to add flour of AHB 1200 biofortified bajra during dahi preparation. Use of bajra flour in preparation of cereal based traditional dairy products like dahi would not only improve the product quality but also provide essential mineral like iron, which will be used to feed children, adolescence girls, and pregnant women suffering from anemia. So present study is proposed with the process for the preparation of buffalo milk.

\section{Materials and Methods}

\section{Preparation of dahi}

During this study flour of iron rich variety of bajra (AHB 1200) and buffalo milk from buffalo unit Dept of AHDS will be utilized for preparation of dahi independently. Milk was Standardize to 6 per cent fat by using Pearson's square formula. The treatment details will be as below

\section{Treatment combinations}

$\mathrm{T}_{1}$ - 100 Parts of milk

$\mathrm{T}_{2^{-}}$98.00 Parts of milk +2 Parts of Bajra flour

$\mathrm{T}_{3}-96.00$ Parts of milk +4 Parts of Bajra flour

$\mathrm{T}_{4}-94.00$ Parts of milk +6 Parts of Bajra flour

$\mathrm{T}_{5}-92.00$ Parts of milk +8 Parts of Bajra flour

\section{Preparation of Dahi}

First the composite buffalo milk was filtered and standardized to 6 per cent fat. It was pasteurized at $80{ }^{0} \mathrm{C}$ for 10 minutes. Bajra flour was added slowly during heating at $70^{\circ}$ C. Milk was cooled down to room temperature. Active dahi starter culture (ncdc167) was inoculated under aseptic conditions 
at the rate of 1.5 per cent and mixed thoroughly. The inoculated milk was incubated at $37{ }^{\circ} \mathrm{C}$ temperature for $12 \mathrm{hrs}$ and dahi was obtained.

\section{Results and Discussion}

\section{Sensory evaluation of Dahi}

The experimental Dahi samples were served to a panel of semi trained judges for sensory evaluation such as, colour and appearance, flavour, body and texture and overall acceptability using "9 point hedonic scale". The numerical score given by judges for individual attribute was computed to obtain mean and these means were subjected to statistical analysis. The data was analyzed statistically by using Completely Randomized Design (CRD) as per Panse and Sukhatme (1985).Results obtained are shown in table 1.

It is noticed from table 1 that the body and texture score for dahi ranged from 8.0 to 9.0. Body and texture score for treatment $\mathrm{T}_{1}, \mathrm{~T}_{2}$, $\mathrm{T}_{3}, \mathrm{~T}_{4}$ and $\mathrm{T}_{5}$ was $9.00,8.75,8.37,8.13$ and 8.00 , respectively. The highest score was recorded for treatment $\mathrm{T}_{1}(9.00)$ prepared entirely from buffalo milk and lowest score (8.0) was obtained for dahi prepared from buffalo milk added with 8 parts $\left(\mathrm{T}_{5}\right)$ of bajra flour. It is also noticed from above table that body and texture decreased with increase in concentration of bajra flour which might be due to increase in viscosity because of higher fibre content in bajra flour. Swarnima et al., (2017) and Dhumal (2017).

It is observed from table 1 that the colour and appearance score for dahi ranged from 9.00 to 6.63. Colour and appearance score for treatment $\mathrm{T}_{1}, \mathrm{~T}_{2}, \mathrm{~T}_{3}, \mathrm{~T}_{4}$ and $\mathrm{T}_{5}$ was 9.00, 8.38, $7.88,7.13$ and 6.63 , respectively. The highest score was recorded for treatment $\mathrm{T}_{1}$ (9.00) prepared entirely from buffalo milk and lowest score (6.63) was obtained for dahi prepared from buffalo milk added with 8 parts $\left(\mathrm{T}_{5}\right)$ of bajra flour. The score of dahi decreased with increase in concentration of bajra flour. All treatments were significantly different from each other and this might be due to dull colour of bajra flour added to milk. Results were comparable with the findings of Padghan et al., (2018) and Syama (2014).

Table.1 Effect of addition of different levels of bajra flour on Overall acceptability score for $d a h i$

\begin{tabular}{|c|c|c|c|c|}
\hline Treatment & $\begin{array}{c}\text { Body and } \\
\text { Texture }\end{array}$ & $\begin{array}{c}\text { Colour and } \\
\text { Appearance }\end{array}$ & Flavour & $\begin{array}{c}\text { Overall } \\
\text { Acceptability }\end{array}$ \\
\hline $\mathbf{T}_{\mathbf{1}}$ & $9.00^{\mathrm{a}}$ & $9.00^{\mathrm{a}}$ & $9.00^{\mathrm{a}}$ & $9.00^{\mathrm{a}}$ \\
\hline $\mathbf{T}_{\mathbf{2}}$ & $8.75^{\mathrm{b}}$ & $8.38^{\mathrm{b}}$ & $8.75^{\mathrm{a}}$ & $8.71^{\mathrm{a}}$ \\
\hline $\mathbf{T}_{\mathbf{3}}$ & $8.50^{\mathrm{c}}$ & $7.88^{\mathrm{c}}$ & $7.88^{\mathrm{b}}$ & $7.79^{\mathrm{ab}}$ \\
\hline $\mathbf{T}_{\mathbf{4}}$ & $8.13^{\mathrm{d}}$ & $7.13^{\mathrm{d}}$ & $7.00^{\mathrm{c}}$ & $7.21^{\mathrm{bc}}$ \\
\hline $\mathbf{T}_{\mathbf{5}}$ & $8.00^{\mathrm{e}}$ & $6.63^{\mathrm{e}}$ & $6.00^{\mathrm{d}}$ & $6.54^{\mathrm{c}}$ \\
\hline $\mathbf{S E}+$ & $\mathbf{0 . 0 8 5}$ & $\mathbf{0 . 1 1}$ & $\mathbf{0 . 0 8 5}$ & $\mathbf{0 . 0 3 2}$ \\
\hline C.D. at 5\% & $\mathbf{0 . 0 2 5}$ & $\mathbf{0 . 3 3}$ & $\mathbf{0 . 0 2 5}$ & $\mathbf{1 . 0 2}$ \\
\hline
\end{tabular}


Flow chart for preparation of dahi lassi

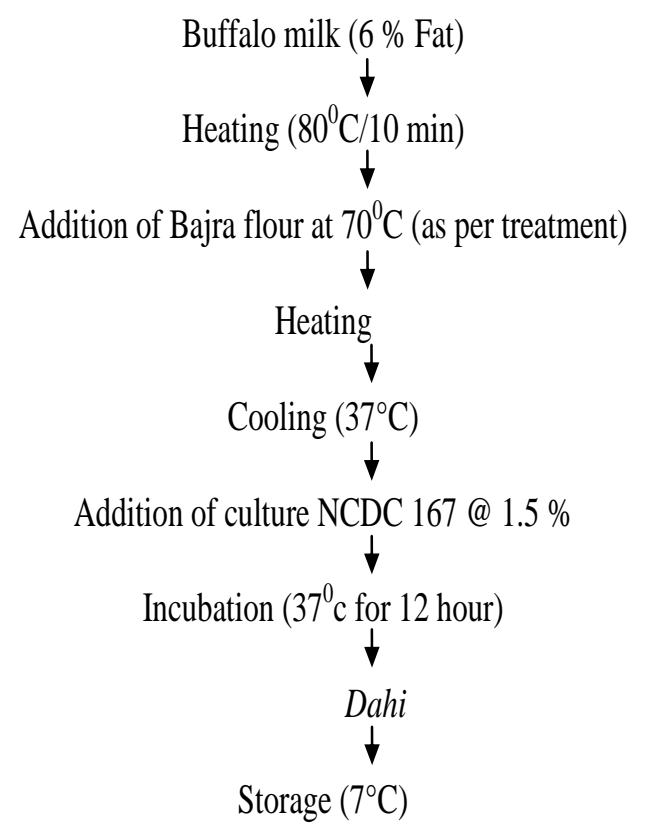

It is noticed that the flavor score for dahi ranged from 9.0 to 6.0. Flavour score for treatment $\mathrm{T}_{1}, \mathrm{~T}_{2}, \mathrm{~T}_{3}, \mathrm{~T}_{4}$ and $\mathrm{T}_{5}$ was $9.00,8.75$, 7.88, 7.00 and 6.00, respectively. The highest score was recorded for treatment $\mathrm{T}_{1}(9.00)$ prepared entirely from buffalo milk while lowest score was recorded for treatment $T_{5}$ (6.00) prepared by replacing 8 parts of buffalo milk with bajra flour. The flavor score of dahi declined with increase in concentration of bajra flour. T1 and T2 were at par while other treatments were significantly different from each other and this might be due to floury flavor of bajra flour which is added to milk. Results were comparable with the findings of Sultana et al., (2006)

Overall acceptability of the dahi for the treatments $\mathrm{T}_{1}, \mathrm{~T}_{2}, \mathrm{~T}_{3}, \mathrm{~T}_{4}$ and $\mathrm{T}_{5}$ were 9.0, $8.71,7.79,7.21$ and, 6.54 respectively. The uppermost overall acceptability score (9.00) was obtained for treatment $\mathrm{T}_{1}$ prepared entirely from buffalo milk while lowermost score was obtained for treatment $\mathrm{T}_{5}$ (6.54) prepared by replacing 8 parts of buffalo milk with bajra flour. Treatment $T_{1}$ and $T_{2}$ were at par while there was no significant difference in treatment $\mathrm{T}_{4}$ and $\mathrm{T}_{5}$. Results were in agreement with the findings of Sultana et al., (2006) noticed that overall acceptability of dahi decreased with increased in concentration of soya solids. Syama (2014) observed overall acceptability score of dahi decreased from 20.66 to 19.51 with increase in flour incorporation from 1 per cent to 3 per cent.

From present investigation it can be concluded that the bajra flour can be very well utilized for preparation of palatable, nutritional fermented dairy products. Although Overall acceptability of dahi decreased from 9.00 to 6.54 but as far as nutritional quality is concern developed dahi is highly nutritious in case of mineral like iron and zinc.

\section{References}

Ali Mam and Abdalla, A. H. (2003). Effect of Fermentation on the In Vitro Protein Digestibility of Pearl Millet. Food 
Chem. Vol. 80(1), 51-54.

Balasubramanian, S. (2013). Processing of Millets. Paper Presented National Seminar on Recent Advances In Processing, Utilization and Nutritional Impact of Small Millets. Madurai Symposium, Thamukkam Grounds, Madurai, 13 Sept, 2013.

Burton, G. W., Wallace, A. T. and Rachie, K. O. 1992. Chemical Composition and Nutritive Value of Pearl Millet (Pennisetum Typhoides) Grain. Crop Science. Vol.12: 187-188.

Chavan, J. K. and Kadam, S. S. (1989). Nutrit ional Improvement of Cereals by Fermentation. In: Critical Rev. in Food Sci. Nutr. Vol. 28(5), 349-400

Dhumal, V. S. (2017). Development of Preparation of Pudina (Mentha Arvensis) Lassi. Master's (Agri.) Thesis Submitted to VNMKV, Parbhani (M.S.).

Habiyaremye, C., Matanguihan, J. B., Alpoim Guedes, J., Ganjyal, G. M., Whiteman, M. R., Kidwell, K. K. and Murphy, K. M. (2017). Proso Millet (Panicum Miliaceum L.) and its Potential for Cultivation in the Pacific Northwest, U.S: A Review. Frontiers in Plant Science, 7, 1961.

Hulse, J. H., Laing, E. M. and Pearson, O. E. (1980). Sorghum and the Millets: Their Composition and Nutritive Value, Academic Press, New York. 187-193.

Mason, J. B. and Garcia, M. (1993).
Micronutrient Deficiency - the Global Situation. SCN News. 9:11-6.

McLean, E., Egli, I., Benoist, B., Wojdyla, D. and Cogswell, M. (2007). Worldwide prevalence of anemia in pre-school aged children, pregnant women and non-pregnant women of reproductive age. In Nutritional Anemia; Kraemer, K., Zimmermann, M.B., Eds.; Sight and Life: Basel, Switzerland. pp. 1-12. Padghan, P. V., Deshmukh N. B., Patil S. P., Mane R. R. and Katore V. D. (2018). Blending of Buffalo milk and Sweet corn milk. Adv. Res. Agri. Vet Sci. 5(3), 21-26.

Panse, Y. P. and Sukatme, P. V. (1967). Statistical Methods for Agricultural Workers, $2^{\text {nd }}$ edn. Indian Council of Agricultural Research, New Delhi.

Swarnima Dey, John David, Bhole Shankar Rai and Kaushal Kishor. (2017). Studies on Sensory Attributes of Cereal Based Fermented Functional Milk. Journal of Pharmacognosy and Phytochemistry. 6(4), 2008-2010.

Sultana, M. N., Wadud, A., Islam, M. N., and Uddin, M. J. (2006). Study on the quality of dahi prepared from Buffalo milk with the addition of different levels of soya milk. J. Bangladesh Agril. Univ. 4(1), 111-116.

Syama, A. M. (2014). Quality Attributes of Probiotic Dahi Incorporated with Foxtail Millet Flour. (Master's thesis) KVAFSU, Bidar, Karnataka.

\section{How to cite this article:}

More, R. V., B. M. Thombre, S. G. Narwade and Sawant, V. Y. 2020. Studies on Sensory Properties of Dahi Blended with Biofortified Bajra Flour. Int.J.Curr.Microbiol.App.Sci. 9(11): 869-873. doi: https://doi.org/10.20546/ijcmas.2020.911.104 